\title{
Endophytic Mycobiota Characterization of the Amazonian Mistletoe Cladocolea micrantha Hosted in Cashew Tree
}

\author{
Anderson C. Guimarães ${ }^{1}$, Antonio C. Siani ${ }^{2 *}$, José L. Bezerra ${ }^{3}$, Antonia Q. Lima de Souza ${ }^{4}$, \\ Maria Inez M. Sarquis ${ }^{5}$
}

${ }^{1}$ Instituto de Ciências Exatas e Tecnologia de Itacoatiara, Universidade Federal do Amazonas, Itacoatiara, Brazil; ${ }^{2}$ Departamento de Produtos Naturais, Farmanguinhos, Fiocruz, Rio de Janeiro, Brazil; ${ }^{3}$ Departamento de Ciências Agronômicas e Ambientais, Universidade Estadual de Santa Cruz, Ilhéus, Brazil; ${ }^{4}$ Laboratório de Genética, Escola Superior de Ciências da Saúde, Universidade Estadual do Amazonas, Manaus, Brazil; ${ }^{5}$ Laboratório de Taxonomia Bioquímica e Bioprospecção de Fungos, Instituto Oswaldo Cruz, Fiocruz, Rio de Janeiro, Brazil.

Email: ${ }^{*}$ siani@far.fiocruz.br

Received March $5^{\text {th }}, 2013$; revised April $3^{\text {rd }}, 2013$; accepted April 12 $2^{\text {th }}, 2013$

Copyright (C) 2013 Anderson C. Guimarães et al. This is an open access article distributed under the Creative Commons Attribution License, which permits unrestricted use, distribution, and reproduction in any medium, provided the original work is properly cited.

\begin{abstract}
Endophytic fungi were identified from different parts of the medicinal parasitic mistletoe Cladocolea micrantha and from its host Anacardium occidentale, suggesting a strict host-parasite relationship. Eight fungal endophytes were isolated and morphologically characterized. The ascomycete Guignardia mangiferae and strains of Mycelia sterilia were prevalent in the isolations. The unequivocal identification of Guignardia mangiferae at a probabilistic degree close to $100 \%$ was carried out by DNA extraction followed by PCR analyses of the ITS- 1 and ITS-2 regions and comparison of the genetic sequence with the NCBI database.
\end{abstract}

Keywords: Cladocolea micrantha; Endophytic mycobiota; Loranthaceae; Guignardia mangiferae; Anacardium occidentale

\section{Introduction}

The Loranthaceae mistletoes, popularly known in Brazil as "erva-de-passarinho" [1] play an important and complex part in the biological system they inhabit, interacting with insects, birds, fishes and mammals [2]. These epiphytic and hemiparasitic plants adhere to the branches and twigs of trees by means of haustoria, penetrating the host to absorb water and nutrients [3]. Species of this family are used all over the world in traditional medicine to treat a wide range of diseases, such as arthritis, diabetes, general inflammation, breathing and nervous problems and some types of cancer [4]. In the Amazonian region, the leaves of the species Cladocolea micrantha (Eichler) Kuijt are widely used in the non-conventional therapy of several types of tumors and inflammatory processes [5], with a preference for specimens growing on the cashew tree Anacardium occidentale (Anacardiaceae) [6]. The genus Cladocolea comprises approximately 40 species and occurs from central to southern Mexico and in some localities of Latin America. The

"Corresponding author. most important morphological feature of this genus is the occurrence of a determinate inflorescence and single lateral ebracteolate flowers or a simple derivative thereof; this characteristic serves to differentiate Cladocolea from other similar mistletoe genera [7]. Chemical studies on this genus are restricted to Cladocolea micrantha which describes the isolation of diverse triterpenes as well as kaempferol and quercetin derivatives presenting an uncommon interglycosidic O- $(1 \rightarrow 3)$ linkage [8]. Complementarily, the triterpenes $\alpha$-amyrin, $\beta$-amyrin and their respective ketones were remarkably characterized from the chloroform extracts of mycelia of G. mangiferae, $P$. clavisporus and P. guepinii 7-d to 14-d-old colonies, isolated from this mistletoe [9].

Endophytic fungal communities occupy intercellular organs in plants, usually inducing an associative relationship that ranges from mutualism to host plant parasitism. Such a symbiosis may confer some protection against insects, herbivores or phytopathogenic microorganisms by producing toxins, antibiotics, specific enzymes or growth-promoting agents and other substances [10]. Endophytic fungi have also been found to be even- 
tually responsible for the bioactive compounds produced by host plants. A corollary to this assumption would be the production of the anti-cancer agent taxol by the endophytic fungi Taxomyces andreanae, Pestalotiopsis microspora and P. guepinii isolated from the Pacific Taxus brevifolia. Similarly, the fungus Phialocephala fortinii isolated from Podophyllum peltatum may produce the antitumoral podophyllotoxin [11,12]. Endophytes have been identified on species associated with many botanical families, and currently, a significant amount of research is focused on obtaining active metabolites from endophytes, aiming to utilize them in medicine and biological control $[11,13,14]$. The present study aimed to identify and to morphologically and molecularly characterize the endophytic fungi from different parts of the parasite mistletoe Cladocolea micrantha and from its host Anacardium occidentale.

\section{Material and Method}

\subsection{Plant Material}

Leaves and stems of Cladocolea micrantha (Eichler) Kuijt and Anacardium occidentale L. for the host-parasite mycobiotic analyses were collected on the campus of the Federal University of Amazonas (UFAM), Manaus, Brazil, S $03^{\circ} 07.785^{\prime}$, W $058^{\circ} 26.631^{\prime}$, each from a single individual host specimen $8 \mathrm{~m}$ tall. Both species were identified, and vouchers were deposited in the Herbarium of UFAM under No. 6213.

\subsection{Surface-Disinfecting and Inoculation of the Botanic Material}

Endophytic fungi were isolated according to the procedure by Petrini $(1992)[15,16]$ using fresh botanical material from both $C$. micrantha and A. occidentale. The plant material was carefully washed with a neutral detergent and running water. After drying, the leaves and stems were sliced into pieces of approximately $8 \mathrm{~cm}^{2}$ and were soaked for $1 \mathrm{~min}$ in a $500 \mathrm{ml}$ beaker containing $70 \%$ ethanol in water. The fragments were then transferred to another beaker containing a 3\% solution of sodium hypochlorite for a period of $4 \mathrm{~min}$. The pieces of leaves and stems were then returned to the beaker containing the ethanol/water solution for $30 \mathrm{~s}$ and were finally transferred to a flask with sterilized water for $1 \mathrm{~min}$. After this procedure, fragments of leaves and stems from both plants were cultured on eight Petri plates (six fragments per plate) containing malt-agar extract (MAE) (Difco) and chloramphenicol (100 $\mu \mathrm{g} / \mathrm{ml}$ MAE) with the aid of a Drigalski loop, resulting in 192 inocula distributed onto 32 plates. A negative control was run by applying $0.05 \mathrm{ml}$ of the distilled water from the last sterilization step onto Petri dishes using the same medium.
Cultured samples were incubated at room temperature (approximately $25^{\circ} \mathrm{C}$ in the laboratory) and observed daily.

\subsection{Endophytic Fungi Isolation and Identification}

After eleven days, the plates contained 160 growing colonies that were singly prepared on slides and carefully inspected under a microscope. Identical fungal strains were separately pooled into eight different representative groups according to their macro- and micromorphological similarities, and their purity was certified by macroand microscopic evaluation. For genus and species assignments, the fungal strains were separately grown on the following media: PDA, malt agar extract (Difco), Czapek-dox agar (Merck) and oatmeal agar (60.0 g oatmeal and $18.0 \mathrm{~g}$ agar). Nutrient-poor synthetic medium agar $\left[1.0 \mathrm{~g} \mathrm{KH}_{2} \mathrm{PO}_{4}, 1.0 \mathrm{~g} \mathrm{KNO}_{3}, 0.5 \mathrm{~g} \mathrm{MgSO}_{4} \cdot 7 \mathrm{H}_{2} \mathrm{O}\right.$, $0.5 \mathrm{~g} \mathrm{KCl}, 0.2 \mathrm{~g}$ glucose, $0.2 \mathrm{~g}$ sucrose and $18.0 \mathrm{~g}$ agar (all Merck) in $1000 \mathrm{ml}$ distilled water] and sunflower seed extract agar were also used according to classical methodologies [17]. The microscopic characteristics were evaluated in microcultures on coverslips in a drop of Amann's lactophenol [20.0 g phenol (Quimibras), 20.0 $\mathrm{ml}$ lactic acid (Merck), $20.0 \mathrm{ml}$ distilled water, $40.0 \mathrm{ml}$ glycerine (Merck)] with $0.05 \mathrm{~g}$ cotton blue (Sigma). The filamentous fungi were classified based on standard procedures reported for morphological characterization [1820]. The fungi were then transferred to test tubes containing MAE for successive growth. Samples were lyophilized and stored under mineral oil in the Fungi Culture Collection Filamentous Fungi of the Oswaldo Cruz Institute, Rio de Janeiro, under Nos. IOC4553 (Aspergillus sp.), IOC 4548 (G. mangiferae), IOC4555 (M. sterilia), IOC4549 (Myrothecium sp.), IOC4550 (P. clavisporus), IOC4551 (P. guepinii), IOC4552 (T. pseudoviridae) and IOC4554 (Drechslera sp.).

\subsection{DNA Extraction and PCR Conditions}

G. mangiferae identification was confirmed by sequencing the ITS-1 and ITS-2 rDNA and comparing it with sequences from GenBank. For ITS-1 and ITS-2 rDNA analyses, the strain was stirred at room temperature for 12 days (120 rpm) on a potato-dextrose medium enriched with $0.2 \%$ PDY (potato dextrose yeast) extract. From $200 \mathrm{mg}$ of mycelium separated by filtration, genomic DNA was extracted using the cetyltrimethylammonium bromide method [21]. Prior to PCR, the DNA concentration was visually estimated at $100 \mathrm{ng} / \mu \mathrm{l}$ by comparing it with the $1 \mathrm{~kb}$ marker on a $1 \%$ agarose gel. Each $25 \mu \mathrm{l}$ of reaction contained $10.2 \mu \mathrm{l}$ of water, $2.5 \mu \mathrm{l}$ of $10 \times$ buffer, $3.0 \mu \mathrm{l}$ of $25 \mathrm{mM} \mathrm{MgCl}_{2}, 3.0 \mu \mathrm{l}$ of $1.25 \mathrm{mM}$ dNTP, $2.0 \mu \mathrm{L}$ each of ITS- 1 and ITS- 2 primers at $10 \mathrm{mM}, 0.3 \mu \mathrm{l}$ of Taq 
DNA polymerase $(5.0 \mathrm{U})$ and $2.0 \mu \mathrm{l}$ of genomic DNA. Four reactions were carried out with an initial denaturing step of $94^{\circ} \mathrm{C}$ for $4 \mathrm{~min}$, followed by 40 cycles of $2 \mathrm{~min}$ denaturing at $94^{\circ} \mathrm{C}, 2 \mathrm{~min}$ annealing at $55^{\circ} \mathrm{C}$ and $2 \mathrm{~min}$ elongation at $72^{\circ} \mathrm{C}$. The amplification was terminated for $10 \mathrm{~min}$ at $72^{\circ} \mathrm{C}$. PCR products were analyzed by electrophoresis on $1.5 \%$ agarose gels stained with ethidium bromide, compared with a DNA ladder of $100 \mathrm{bp}$ and estimated at $50 \mathrm{ng} / \mu \mathrm{l}$. In all, $2 \mu \mathrm{l}$ of the PCR products were sequenced on an acrylamide gel, and the sequences obtained were matched with those deposited in the NCBI (National Center for Biotechnology Information) database.

\section{Results and Discussion}

A total of 160 fungal strains (from the 192 total fragments of plant material) comprising 8 groups of endophytic fungi were isolated from both mistletoe and the plant host. Stems and leaves of the mistletoe Cladocolea micrantha led to the isolation of the following fungal species and genera: Aspergillus sp. (Trichocomaceae, Order Eurotiales), Guignardia mangiferae (Botryosphaeriaceae, Order Botryosphaeriales) Mycelia sterilia (deuteromycetes, Order Agonomycetales), Myrothecium sp. (Incertae sedis, Order Hypocreales), Paecilomyces clavisporus (Trichocomaceae, Order Eurotiales), Pestalotiopsis guepinii (Amphisphaeriaceae, Order Xylariales) and Trichoderma pseudoviridae (Hypocreaceae, Order Hypocreales). The following species and genera were identified in the tissues of Anacardium occidentale: Pestalotiopsis guepinii, Drechslera sp. (Pleosporaceae, Order Pleosporales), Guignardia mangiferae, Mycelia sterilia, and Trichoderma pseudoviridae. The three species/genera in boldface were common to both the parasite and the host plant (Table 1). All of these occurrences are described here for the first time, especially for the Cladocolea micrantha mycobiota, for which, as far as we know, this is the first report.

The non-sterile ascomycetes G. mangiferae and Mycelia sterilia were found as the most frequent fungal endophytes in both the parasite and the host plants in the experimental sampling. Identification of G. mangiferae was based on macroscopic characteristics and on the microscopic measurements of individuals from the 7-d-old colony on MAE, which presented the following dimensions: pseudothecia $[(640-1232) \times(112-424) \mu \mathrm{m}]$; ostioles $[(80-400) \times(80-200) \mu \mathrm{m}]$; asci $[(40-68) \times$ $(10-12) \mu \mathrm{m}$; ascospores [(15 - 16) $\times(5-6) \mu \mathrm{m}][22]$. Similar results for the ascospore sizes $[(13-17) \times(5-8)$ $\mu \mathrm{m}]$ were observed for G. mangiferae isolated from Anacardium giganteum [23]. The trusted pairwise comparisons revealed $99 \%$ identity with G. mangiferae and $100 \%$ reliability for the 576 DNA base pairs (data not shown). Such a high probabilistic correlation provides additional relevant data on tropical endophytes, given that the Guignardia species present wide intraspecific genetic variability [24,25]. Species of Guignardia are usually recognized as endophytic fungi and have been isolated from asymptomatic tissues from a diversity of Myrtaceae and Anacardiaceae species as well as citrus plants [25]. However, some species such as G. citricarpa and G. psidii cause serious diseases to agriculture by infesting fruit and leaves post-harvest. General studies of endophytes are more prevalent in temperate regions [26] and should be extended to tropical species when considering the pharmaceutical potential of tropical medicinal plants [27].

\section{Conclusion}

The findings reported here reinforce the cosmopolitan occurrence of the endophytic G. mangiferae in tropical plants $[23,28,29]$. The non-sterile mycobiota of the leaves of both parasitic and host plants is characterized by the common presence of G. mangiferae as the most frequently occurring fungus. This presence was not observed for the

Table 1. Endophytic fungi characterized in the tissues of Cladocolea micrantha and Anacardium occidentale.

\begin{tabular}{|c|c|c|c|c|}
\hline Fungus species & CM leaf & $\mathrm{CM}$ stem & AO leaf & AO stem \\
\hline Aspergillus sp. [2] & $\mathrm{n}$ & $\mathrm{n}$ & $2 / 10$ & $\mathrm{n}$ \\
\hline Drechslera sp. [1] & $\mathrm{n}$ & $\mathrm{n}$ & $1 / 10$ & $\mathrm{n}$ \\
\hline Guignardia mangiferae [15] & $8 / 15$ & $\mathrm{n}$ & $7 / 10$ & $\mathrm{n}$ \\
\hline Myrothecium sp. [2] & $1 / 15$ & $1 / 18$ & $\mathrm{n}$ & $\mathrm{n}$ \\
\hline Mycelia sterilia [133] & $31 / 15$ & $38 / 18$ & $35 / 10$ & $29 / 3$ \\
\hline Paecilomycesclavisporus [2] & $2 / 15$ & $\mathrm{n}$ & $\mathrm{n}$ & $\mathrm{n}$ \\
\hline Pestalotiopsis guepinii [2] & $\mathrm{n}$ & $2 / 18$ & $\mathrm{n}$ & $\mathrm{n}$ \\
\hline Trichoderma pseudoviridae [3] & $1 / 15$ & $\mathrm{n}$ & $1 / 10$ & $1 / 3$ \\
\hline
\end{tabular}

$\mathrm{CM}=$ Cladocolea micrantha $; \mathrm{AO}=$ Anacardium occidentale . In brackets $=$ total of similar pooled strains. Results $(\mathrm{X} / \mathrm{Y})$ indicate the ratio of culture plates $(\mathrm{X})$ growing positively over the total cultured plates $(\mathrm{Y})$, including replication experiments; $\mathrm{n}=$ no growth observed. 
stems, suggesting that some horizontal fungal contamination (leaf-leaf) cannot be excluded [30]. This is the first description of G. mangiferae as an endophyte in $C$. micrantha. Moreover, its presence on A. occidentale suggests a close host-parasite relationship, a fact that may be relevant to the medicinal properties of the parasite plant and to the popular preference for G. mangiferae grown on this host plant.

\section{Acknowledgements}

The authors wish to thank Dra. Lilian A. Procópio for the plant identification, and plant collectors Silo Silva and Rosalba Bilby for their help.

\section{REFERENCES}

[1] H. Lorenzi, "Plantas Daninhas do Brasil: Terrestres, Aquáticas, Parasitas e Tóxicas," 3rd Edition, Instituto Plantarum, Nova Odessa, 2000.

[2] D. M. Watson, "Mistletoe-A Keystone Resource in Forest and Woodlands Worldwide," Annual Review of Ecological System, Vol. 32, 2001, pp. 219-249. doi:10.1146/annurev.ecolsys.32.081501.114024

[3] J. E. L. S. Ribeiro, M. J. G. Hopkins, A. Vicentini, C. A. Sother, M. A. S. Costa, J. M. Brito, M. A. D. Souza, L. H. P. Martins, L. G. Lohmann, P. A. C. L. Assunção, E. C. Pereira, C. F. Silva, M. R. Mesquita and L. C. Procópio, "Flora da Reserva Ducke: Guia de Identificação das Plantas Vasculares de uma Floresta de Terra-Firme na Amazônia Central," Instituto Nacional de Pesquisas da Amazônia, Brazil, 1999.

[4] A. C. Guimarães, "Estudo Químico e Biológico de Cladocolea micrantha (Loranthaceae), uma planta medicinal da região Amazônica," Doctorate Thesis, Universidade Federal do Rio de Janeiro, Brazil, 2005.

[5] A. Cáceres, "Plantas de Uso Medicinal en Guatemala," Editorial Universitaria, San Carlos de Guatemala, 1996.

[6] J. Kuijt, "Inflorescence Structure and Generic Placement of Some Small-Flowered Species of Phthirusa (Loranthaceae)," Systematic Botany, Vol. 16, No. 2, 1991, pp. 283-291. doi: $10.2307 / 2419280$

[7] A. C. Guimarães, R. M. Kuster, A. C. F. Amaral, J. L. P. Ferreira and A. C. Siani, "Histological Study of the Leaf and Stem of the Amazonian Medicinal Mistletoe Cladocolea micrantha (Loranthaceae)," International Journal of Botany, Vol. 3, No. 2, 2007, pp. 218-221. doi:10.3923/ijb.2007.218.221

[8] A. C. Guimarães, A. Magalhães, M. J. Nakamura, A. C. Siani, A. L. F. Sampaio and C. Barja-Fidalgo, "Flavonoids Bearing an $O$-arabinofuranosyl- $(1 \rightarrow 3)$-Rhamnoside Moiety from Cladocolea micrantha: Inhibitory Effect on Human Melanoma Cells," Natural Product Communications, Vol. 7, No. 10, 2012, pp. 1311-1314.

[9] A. C. Guimarães, R. M. Kuster, I. Neves Jr., M. C. S. Lourenço and M. I. Sarquis, "Preliminary Investigation on the Mycelial Composition and Antimicrobial Potential of Endophytic Fungi from the Amazonian Mistletoe Cla- docolea micrantha (Eichler) Kuijt (Loranthaceae)," Revista Fitos, Vol. 4, No. 2, 2009, pp. 90-101.

[10] A. V. Sturtz, B. R. Christie, B. G. Matheson, W. J. Arsenault and N. A. Buchanan, "Endophytic Bacterial Communities in the Periderm of Potato Tubers and Their Potential to Improve Resistance to Soil-Borne Plant Pathogens," Plant Patholology, Vol. 48, No. 3, 1999, pp. 360-369. doi:10.1046/j.1365-3059.1999.00351.x

[11] G. Strobel and B. Daisy, "Bioprospecting for Microbial Endophytes and Their Natural Products," Microbiology and Molecular Biological Reviews, Vol. 67, No. 4, 2003, pp. 491-502. doi:10.1128/MMBR.67.4.491-502.2003

[12] A. L. Eyberger, R. Dondapati and J. R. Porter, "Endophyte Fungal Isolates from Podophyllum peltatum Produce Podophyllotoxin," Journal of Natural Products, Vol. 69, No. 8, 2006, pp. 1121-1124. doi:10.1021/np060174f

[13] G. Strobel, B. Daisy, U. Castillo and J. Harper, "Natural Products from Endophytic Microorganisms," Journal of Natural Products, Vol. 67, No. 2, 2004, pp. 257-268. doi:10.1021/np030397v

[14] K.-H. Kogel, P. Franken and R. Hückelhoven, "Endophyte or Parasite-What Decides?" Current Opinion in Plant Biology, Vol. 9, No. 4, 2006, pp. 358-363. doi:10.1016/j.pbi.2006.05.001

[15] O. Petrini, T. N. Sieber, L. Toti and O. Viret, "Ecology, Metabolite Production and Substrate Utilization in Endophytic Fungi," Natural Toxins, Vol. 1, No. 3, 1992, pp. 185-196. doi:10.1002/nt.2620010306

[16] A. Q. L. Souza, A. D. L. Souza, S. Astolfi-Filho, M. L. B. Pinheiro, M. I. M. Sarquis and J. O. Pereira, "Atividade Antimicrobiana de Fungos Endofíticos Isolados de Plantas Tóxicas da Amazônia: Palicourea longiflora (Aubl.) Rich. e Strychnos cogens Bentham," Acta Amazonica, Vol. 34, No. 2, 2004, pp. 185-195. doi:10.1590/S0044-59672004000200006

[17] S. T. Jaronski and R. C. Axtell, "Simplified Production System for the Fungus Lagenidium giganteum for Operational Mosquito Control," Mosquito News, Vol. 44, No. 3, 1984, pp. 377-381.

[18] M. B. Ellis, "More Dematiaceous Hyphomycetes," CAB Press, Kew, 1976.

[19] B. C. Sutton, "The Coelomycetes: Fungi Imperfecti with Pycnidia, Acervuli and Stromata," Commonwealth Mycological Institute, Kew, 1980.

[20] J. J. Pitt, "A Laboratory Guide to Common Penicillium Species," Academic Press, Autralia, 1985.

[21] T. J. White, T. L. Bruns, S. Lee and J. W. Taylor, “Amplication and Direct Sequencing of Fungal Ribosomal RNA Genes for Phylogenetics," In: M. Innis, D. H. Gelfand, J. J. Sninsky and J. T. White, Eds., PCR Protocols: A Guide to Methods and Applications, Academic Press, Waltham, 1990, pp. 315-322.

[22] A. J. Roy, "Some Fungi from Almora," Indian Phytopathology, Vol. 20, No. 21, 1968, pp. 340-348.

[23] K. F. Rodrigues, T. N. Sieber, C. R. Grünig and O. Holdenrieder, "Characterization of Guignardia mangiferae Isolated from Tropical Plants Based on Morphology, ISSR-PCR Amplifications and ITS1-5.8S-ITS2 Sequen- 
ces," Mycological Research, Vol. 108, No. 1, 2004, pp. 45-52. doi:10.1017/S0953756203008840

[24] C. Glienke-Blanco, C. I. Aguilar-Vildoso, M. L. C. Vieira, P. A. V. Barroso and J. L. Azevedo, "Genetic Variability in the Endophytic Fungus Guignardia citricarpa Isolated from Citrus Plants," Genetic and Molecular Biology, Vol. 25, No. 2, 2002, pp. 251-255. doi:10.1590/S1415-47572002000200021

[25] E. Wickert, A. Góes, E. G. M. Lemos, A. Souza, E. L. Silveira, F. D. Pereira and D. Rinaldo, "Relações Filogenéticas e Diversidade de Isolados de Guignardia spp. Oriundos de Diferentes Hospedeiros nas Regiões ITS1-5, 8s-ITS2," Revista Brasileira de Fruticultura, Vol. 31, No. 2, 2009, pp. 360-380. doi:10.1590/S0100-29452009000200010

[26] N. S. Raviraja, "Fungal Endophytes in Five Medicinal Plant Species from Kudremukh Range, Western Ghats of India," Journal of Basic Microbiology, Vol. 45, No. 3, 2005, pp. 230-235. doi:10.1002/jobm.200410514

[27] G. Strobel, B. Daisy and U. Castillo, "The Biological
Promise of Microbial Endophytes and Their Natural Products," Plant Patholology Journal, Vol. 4, No. 2, 2005, pp. 161-176. doi:10.3923/ppj.2005.161.176

[28] R. P. Baayen, P. J. Bonants, G. Verkley, G. C. Carroll, H. A. van der Aa, M. de Weerdt, I. R. van Brouwershaven, G. C. Schutte, W. Maccheroni, C. G. de Blanco and J. L. Azevedo, "Nonpathogenic Isolates of the Citrus Black Spot Fungus, Guignardia citricarpa, Identified as a Cosmopolitan Endophyte of Woody Plants, Guignardia Mangiferae (Phyllosticta capitalensis)," Phytopathology, Vol. 92, No. 5, 2002, pp. 464-477. doi:10.1094/PHYTO.2002.92.5.464

[29] M. V. Tejesvi, M. S. Nalini, B. Mahesh, H. S. Prakash, K. R. Kini, H. S. Shetty and V. Subbiah, "New Hopes from Endophytic Fungal Secondary Metabolites," Boletin de la Sociedad Química de México, Vol. 1, No. 1, 2007, pp. 1926.

[30] A. M. M. N. Pirttil, "Endophytes in the Buds of Scots Pine (Pinus silvestres L.)," M.Sc. Dissertation, University of Oulu, Oulu, 2001. 